\title{
ZAKAT MANAGEMENT IN THE COVID-19 PANDEMIC ERA
}

\author{
Norvadewi' ${ }^{1}$, Akhmad Nur Zaroni ${ }^{2}$, Fitria Rahmah ${ }^{3}$ \\ 1,2,3Faculty of Islamic Economics and Business, \\ Universitas Islam Negeri Sultan Aji Muhammad Idris Samarinda \\ Jalan H.A.M. Rifaddin, Loa Janan Ilir, Samarinda, East Kalimantan, \\ 75251, Indonesia
}

$\triangle$ Corresponding Author:

Nama Penulis: Fitria Rahmah

E-mail: fitria.rahmah@iain-samarinda.ac.id

\section{Abstract}

The study aims is to show how the zakat management in the covid-19 pandemic era. Amil zakat institutions need to make innovation in term of zakat management, both collection and distribution of zakat itself, one of them is related to the digitization of zakat management. This research analysed with a qualitative approach. The results showed that East Kalimantan LAZ DPU had innovated in terms of zakat management by utilizing digital technology both in the collection and distribution of ZIS funds. In the distribution of ZIS funds, it was directed at handling the impact of covid-19 for Mustahik to help Mustahik economic difficulties through regular programs in the field of humanity, da'wah, health, economy, and education. In addition, some special programs were also added, namely helping medical personnel by providing personal protective equipment, the best frontline nutrition program, providing basic food supply for the dhuafa, and empowering students and teachers during this pandemic. This research show that LAZ do an action in humanity specially in pandemic era.

Keywords: Zakat Management, Covid-19 Pandemic, Digital technology

\begin{abstract}
Abstrak
Penelitian ini bertujuan untuk menunjukkan bagaimana pengelolaan zakat di era pandemi covid-19. Lembaga amil zakat perlu melakukan inovasi dalam hal pengelolaan zakat, baik penghimpunan maupun penyaluran dana, salah satunya terkait dengan digitalisasi pengelolaan zakat. Penelitian ini dianalisis dengan pendekatan kualitatif. Hasil penelitian menunjukkan bahwa DPU LAZ Kaltim telah melakukan inovasi dalam hal pengelolaan zakat dengan memanfaatkan teknologi digital baik dalam penghimpunan maupun penyaluran dana ZIS. Dalam penyaluran dana ZIS diarahkan pada penanganan dampak covid-19 bagi Mustahik. Misalnya, untuk membantu kesulitan ekonomi Mustahik melalui program reguler di bidang kemanusiaan, dakwah, kesehatan, ekonomi, dan pendidikan. Selain itu, beberapa program khusus juga ditambahkan, yaitu membantu tenaga medis dengan menyediakan alat pelindung diri, program nutrisi garda terdepan terbaik, pemberian sembako bagi para dhuafa, dan pemberdayaan siswa dan guru di masa
\end{abstract}


pandemi ini. Penelitian ini menunjukkan bahwa LAZ melakukan aksi kemanusiaan khususnya di era pandemi.

Kata kunci: Manajemen Zakat; Pandemi Covid-19; Teknologi Digital

\section{INTRODUCTION}

Corona Virus Disease 2019 (COVID-19) which appeared at the end of 2019 in Wuhan and developed into a global pandemic has become a crucial world problem (Chakraborty \& Maity, 2020). Various countries are trying to solve various problems as its effects, not only focusing on solving health problems (Bambra et al., 2020; Tiirinki et al., 2020; Trougakos et al., 2020; Wang \& Tang, 2020), but also anticipate the socioeconomic impacts of this pandemic (Almeida \& Santos, 2020; Bernauer \& Slowey, 2020; IbnMohammed et al., 2021).

One of the socio-economic impacts of the spread of COVID-19 is that some sectors of industry have been affected and failed to survive. It caused an increase in layoffs (Termination of Employment) and unemployment (Eichhorst et al., 2020; Karmaker et al., 2021; Mofijur et al., 2020). Socioeconomic impact of the COVID-19 pandemic is also felt by Indonesia. The first positive case of COVID-19 was confirmed in March 2020, until today, the total cumulative confirmed cases reach 2,417,788 (World Health Organization, 2020).

The high number of cases in Indonesia has made the government to intervene in issuing a series of programs and policies to mitigate the spread of COVID-19, such as the Adaptation of New Habits (New Normal) and LargeScale Social Restrictions (PSBB)/ The Enforcement of Community Activities Restrictions (PPKM). In such conditions, it has effect on the Indonesian economy, it is marked by a decline in the growth of GDP growth in the second and third quartal of 2020 (Badan Pusat Statistik, 2020).

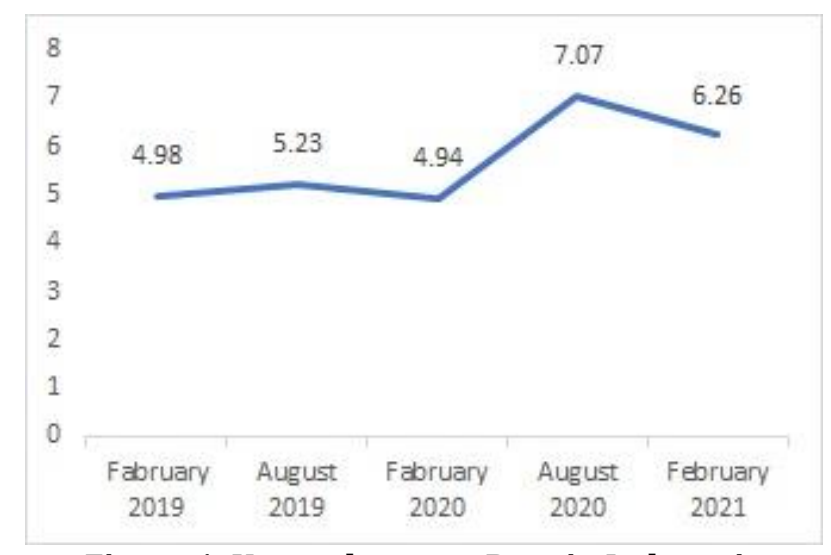

Figure 1. Unemployment Rate in Indonesia Source: BPS, 2021 
From the Figure 1, In addition, the increase of the percentage of unemployment in the period August 2020 to February 2021 compared to the previous period before COVID-19 spread everywhere, it also became an accelerator in the increase of poverty in Indonesia, starting from September 2020 , as many as 27.55 million people or an increase of $0.91 \%$ compared to September 2019 (The Central Bureau of Statistics, 2021). The implication is that Indonesia needs to expand its social protection program which has aim in helping the new poor as well as the existing poor.

The social financial system in Islam can be a solution to overcome some existing economic problems, namely by optimizing zakat and waqf instruments to reduce poverty level (Hassan, 2010; Beik \& Arsyianti, 2013; Shaikh, 2016). In this case, zakat management institutions in Indonesia, both the National Amil Zakat Agency (BAZNAS) and the Amil Zakat Institute have an important role in anticipating the impact of the spread of the virus. There are various efforts which can be done, including preventive efforts by educating the public about healthy living, curative efforts by providing health facilities that support in the effort to meet the need of the poor society who are affected by the corona-19 virus (Nurhidayat, 2020).

There are several challenges which faced by the Amil Zakat Agency or Institution, namely the realization of zakat fund collection is much lower than the projection (Asfarina et al., 2019). It was indicated by the results of potential zakat projections which carried out by Asfarina et al. (2019) using the Contemporary Fiqh approach. It showed that zakat funds which could be collected in Indonesia was as much as 216.54 trillion rupiah, or it was equivalent to $1.75 \%$ of GDP (Asfarina et al., 2019), while the realization of zakat fund collection in 2017 was only 4.19 trillion. This showed that the process of collecting zakat funds was not optimal yet. Another problem faced by BAZ and LAZ in this COVID-29 pandemic was the recommendation to do physical distancing or distance restriction to control the spread of COVID-19 (Newbold et al., 2020), so that with some of the challenges faced by those two institutions, BAZ and LAZ are expected to adapt and innovate in the management of zakat funds which managed during this pandemic.

Although research related to the management of zakat funds in this pandemic had been carried out by (Amanda et al., 2021) shows that zakat funds are distributed into three health emergency sectors, socio-economic emergency sectors, and based on existing programs. In addition, BAZNAS also helps preachers who have been affected by the Covid-19 virus. This means that the implementation of zakat in handling Covid-19 has a very large impact on the surrounding community. Meanwhile, Ansoriyah et al. (2020) shows that the management of zakat by the localization system has a great 
opportunity for the Zakat Collection Unit/Unit Pengumpul Zakat (UPZ) of the mosque to help optimally handle the community affected by the pandemic. In addition, the role of UPZ in overcoming the impact of the pandemic only occurs during the fasting month and has not maximized the use of zakat mal. The lack of guidance from BAZNAS on the role of UPZ makes the implementation of the function of the mosque's UPZ not run well. The absence of reporting and monitoring activities is also one of the weaknesses of the mosque UPZ.

Baskoro \& Karmanto (2020) say that perceived ease of use, perceived usefulness, and trust have a positive effect on behavioural intentions. Perceived usefulness mediates the effect of perceived ease of use and trust on behavioural intentions. This research is expected to provide benefits related to policies through the use of a crowdfunding platform to increase behavioural intentions to distribute zakat, donations, and shodaqoh. Nurhidayat (2020) states that zakat institutions in Indonesia Badan Amil Zakat Nasional (BAZNAS) and Lembaga Amil Zakat (LAZ) are currently still integrating manual and digital collections. These two strategies are still the mainstay, it is adjusted to the zakat payer (muzakki) segmentation. The segmentation of muzakki in urban areas and millennial muzakki prefer digital fundraising. Integrating manual and digital answers needs while making it easier for muzakki and paying zakat.

Iskandar et al. (2020) conducted research at East Kalimantan LAZ and Ummah Care Fund/Dana Peduli Umat (DPU). The results of this study indicate that the East Kalimantan DPU LAZ has a pure fund distribution program without repayment and distribution in the form of loans. However, the SWOT analysis conducted by Iskandar et al. (2020) shows that the East Kalimantan DPU LAZ has weaknesses including; 1) The institution lacks human resources so that it is quite difficult to continue the program of activities at the institution; 2) Receiver Zakat (Mustahik) from East Kalimantan LAZ DPU did not receive continuous guidance, resulting in business failure. However, East Kalimantan LAZ DPU. Based on the contradictory findings by Amanda et al. (2021), Ansoriyah et al. (2020), Baskoro \& Karmanto (2020), Nurhidayat (2020). The researchers felt the need to review the management of zakat in East Kalimantan LAZ DPU, especially during the pandemic.

\section{LITERATURE REVIEW}

The Role of Islamic Economics and Social Finance in This Covid-19 Pandemic

Indonesia as a country with the largest Muslim population in the world is expected to play its best role through various forms or models of 
philanthropy in Islamic Economics and Finance, especially in this Covid-19 pandemic. This role is expected to be able to overcome economic shocks which occurs in all communities, especially Muslims and contributes to recover it.

Iskandar, et al offer solutions in form of conceptual framework and Islamic economic system and Islamic social finance systems, namely: distributing direct cash assistance from zakat, infaq and alms, so that Muslims are encouraged to pay zakat, infaq and alms (Iskandar et al., 2020). Especially for zakat, it is focused on the poor who are directly affected by COVID-19; Strengthening cash waqf with various schemes, such as cash waqf, productive waqf and waqf linked sukuk. Waqf Institution of Indonesia needs to work with Islamic financial institutions to promote these waqf schemes, which will later be used to develop waqf-based infrastructure, such as the Waqf Hospital specifically for Covid-19 victims, waqf Personal Protective Equipment, waqf masks, waqf polyclinics, Waqf of Isolation House, procurement of waqf ventilators, waqf universities and so on. Waqf management must be done professionally so that waqf can be used productively and sustainably, Excellent business capital assistance during a crisis. SMEs which are most affected by Covid-19 make them difficult to survive and experience bankruptcy so that they fall into poverty and increase the number of Mustahik zakat; Business capital through qardhul hasan financing.

This product is one of the most important products in supporting the recovery or supporting the economy; Besides the Islamic banking sector and qardhul hasan, some of the funds which collected by zakat collection units or organizations, especially those in the regions, it can be used to strengthen SMEs businesses that are threatened with bankruptcy due to the impact of Covid-19 so that they are classified as poor, fi sabilillah or gharimin; Improving Islamic economic and financial literacy through the provision of Islamic economic education assistance for students affected by Civod-19, giving permits and facilities for State and Private Universities to run Distance Learning (PJJ) programs which offer the Sharia Economics programs with more emphasis on moral and ethical development and the expansion of internet connection infrastructure supporting PJJ that is evenly distributed throughout Indonesia for free; and developing sharia financial technology so that those above programs, especially direct cash assistance, zakat, infaq, waqf, or Corporate Social Responsibility (CSR) can really be encouraged. It is hoped that it will help the economic surplus to be re-formed so that the acceleration of economic recovery can be realized (Iskandar et al., 2020).

According to Hudaefi et al. (2021) zakat institutions have an important and strategic role to help the government to prevent the Covid-19 
considering its position as a philanthropic organization, specifically there are several sectors in which zakat could be donated as some roles. First, the role in the economic sector, Covid-19 slows down the global economic growth which will create new Mustahik potentials. In a global context, zakat institutions can work with World Zakat Forum (WZF) to discuss opportunities for distributing zakat for prevention, treatment, and research on Covid-19 vaccines. In addition, in collaboration with WZF, zakat institutions around the world can advocate for the role of zakat in dealing with the economic downturn in WZF member countries due to Covid-19. In the national and local context, zakat distribution in the economic sector can be increased by empowering new Mustahik due to weak global economic growth as the effect of Covid-19.

Second, the roles in the Educational, Social and Humanitarian sectors, the Covid-19 virus opens opportunities for zakat institutions to expand their roles in the educational, social and humanitarian fields. For example, zakat institutions can distribute infaq funds to do preventive actions from the individual level. In addition, zakat institutions can also socialize the dangers of Covid-19 internally in zakat institutions and through their media campaigns so that it can be consumed by the public. Specifically, in the humanitarian field, zakat institutions and WZF need to work together in campaigning for the importance of consuming halal food which is supported by scientific evidence.

Third, the role in the health sector, zakat institutions cooperate with relevant health stakeholders in expanding their role to conduct studies and research related to the Covid-19 vaccine, and for zakat institutions which have health units, the zakat institutions can increase capacity or providing laboratory equipment which can detect patients who has been infected with Covid-19.

Fourth, the role in the da'wah sector, zakat institutions can campaign on a large scale the urgency of consuming halal food to protect themselves from viruses in non-halal animals. This campaign must be supported by religious beliefs and scientific evidence to protect oneself from viruses found in nonhalal animals by consuming halal food (Ansoriyah et al., 2020).

\section{Digitizing Zakat Management in This Covid-19 Pandemic}

We are currently in digital era that displays various technological advantages. The use of digital technology can increase time efficiency and other easiness things and advantages for human life, including the management of zakat. According to Soleh (2019) in raising Zakat Infaq Shodaqoh (ZIS) funds, zakat institutions must always carry out education, socialization, promotion and transferring information in order to create 
understanding, awareness and the need of prospective muzakki/donors to be willing to give their ZIS. Zakat institutions need to plan appropriate strategies and approaches in fundraising so that funds can be collected maximally. On the other hand, Beik \& Arsyianti (2013) considers that the challenge of zakat management in Indonesia is on the distribution side, so that it must be strengthened by programs that are substantively right on the target. Strengthening on the distribution side will increase trust. The official amil zakat institution can maintain trust with various programs which conducted in the field so that zakat growth will increase and will help to increase and maintain economic stability because the Mustahik group is helped, purchasing power increases and all of us will feel the benefits.

An important and very effective strategy in digital era is to take full advantage of digital technology because the role of digital technology, especially media, it increasingly important in all aspects of life. The expansion in social media should be further strengthened. Through social media, various things can be done, such as socialization, campaigns, and program interventions. Therefore, philanthropic institutions should take advantage of existing digital channels. According to Rohim (2019), currently what zakat institutions need is the transformation of zakat fundraising strategies from conventional to digital fundraising. This transformation is a must because of the development of technology that characterizes modern society who are the user of technology.

The advancement of digital technology was utilized by the National Amil Zakat Agency (BAZNAS) in realizing the Zakat Awakening Period 20162020 with the implementation of digital technology in the management of national zakat which was marked by the launching of national data entry by BAZNAS on November 5, 2016. digital services are expected to increase public trust and give easiness for muzakki to pay zakat through statemandated Zakat Management Organizations, namely: BAZNAS, provincial BAZNAS, district/city BAZNAS and Amil Zakat Institution (LAZ). To realize this revival of zakat, BAZNAS is currently utilizing the momentum of the digital era to improve its organizational performance and achieve the goals of zakat management as mandated by Law No. 23 of 2011 concerning Zakat Management, namely: First, improving the effectiveness and efficiency of services in the management of zakat. Second, increasing the benefits of zakat to realize community welfare and poverty alleviation (Bahri \& Khumaini, 2020).

BAZNAS has compiled the National Zakat Management Strategic Plan 2016-2020 with a focus on six aspects, namely first, the legal aspect with the publishing of a Decree on the establishment of an institution and a Decree for the leadership elements of Provincial BAZNAS and Regency/City BAZNAS 
which has been adjusted to Law No. 23 of 2011 regarding to the Zakat Management, there are 33 provinces and 397 regencies/cities. Second, aspects of accountability and compliance with sharia. For BAZNAS, Provincial BAZNAS and Regency/Municipal BAZNAS, this aspect includes periodic reports and accountability, approval of annual RKAT, audit of financial report by Public Accounting Firm (KAP) and sharia audit. Meanwhile, LAZ includes periodic reports and accountability, audits of financial reports by KAP and sharia audits. To provide a guarantee so that the management of national zakat can run in accordance with Islamic sharia and applicable laws and regulations, sustainable guidance and supervision is needed both in terms of finance, programs, and compliance with Sharia.

Third, aspects of IT and systems. Provincial BAZNAS, Regency/City BAZNAS implement the Management Information System of BAZNAS (SiMBA) properly and LAZ is well integrated with SiMBA, so that the reports to the President and national zakat stakeholders can be submitted regularly and on time. The presence of SiMBA is designed for the purposes of making reports, storing data and information which owned by BAZNAS as an institution that is mandated to be the coordinator of zakat management nationally. Through web based, SiMBA is a centralized application so that it can be used by Provincial BAZNAS, Regency/City BAZNAS and LAZ without having to go through a complicated installation process.

Fourth, the distribution aspect, which is based on the Zakat Core Principle, the performance assessment of zakat distribution is seen from the ratio of distribution to zakat collection. The higher the ratio of distribution to collection of zakat, the more effective the management of zakat by prioritizing poverty alleviation. Fifth, the collection aspect. To make zakat collection to be optimal nationally, zakat institution needs to educate muzakki in form of national zakat campaign that is done continuously and will give birth to trust to the zakat institutions. Sixth, the aspect of amil development. To improve and standardize the capacity and competence of amil nationally, it is necessary to conduct appropriate training and coaching and refer to national standard.

From those six aspects above, in today's digital era, the information technology aspect needs to continue to get great attention. On one side, to realize it, large investment is needed to meet technology infrastructure. But on the other hand, the use of appropriate technology will increase the effectiveness and efficiency of national zakat management. Through the increase of collection of zakat nationally, various strategic programs for Mustahik can be realized through a variety of services, including education programs, health programs, economic programs, humanitarian programs, etc. It is hoped that in this digital era, it will provide easy access for muzakki to 
pay zakat and provide convenience for amil both in planning, distributing and utilizing as well as reporting of national zakat management (Bahri \& Khumaini, 2020). This is in line with the finding of Muneeza \& Nadwi (2019) regarding the potential of application-based technological innovations in zakat management in India that the fundraising strategy is a need to improve zakat organizational governance and strengthen the institution as well as opportunities and challenges in the digital era by digitizing zakat management as has been done in India.

Although applying technology in its management, Rachman \& Salam (2018) recommended that zakat management must be in accordance with sharia principles, zakat institutions must meet the provisions and standardization in two aspects, which include contract stipulation, administrative costs, and calculation of zakat and in term of financial report, it must also match with the rules and Islamic financial reporting standards. Furthermore, for institutional strengthening, it is necessary to do continuously sharia supervision until the development of systems and management of zakat which follows the development of fintech can be reached.

\section{METHOD}

This study is qualitative research using an inductive and analytical approach to explain and analyse the zakat management which done by LAZ Dana Peduli Ummat (LAZ Care Fund for Ummah/ LAZ DPU), East Kalimantan in the era of COVID-19 pandemic. The purpose of this descriptive research was to create a factual and accurate description of digital technology-based Zakat Management at LAZ Care Fund for Ummah, East Kalimantan during the covid -19 pandemic. Some primary data were collected using interviews (Manager, amil and Mustahik) and observations as well as documentation then analysed using triangulation (Sugiyono, 2017).

\section{RESULT AND DISCUSSION}

East Kalimantan LAZ DPU which was established in 2007 is one of seven Amil Zakat Institutions in Indonesia that received legality from the Ministry of Religion and the central BAZNAS in 2016 as a provincial LAZ. Currently, the central of East Kalimantan LAZ DPU is in Samarinda city, and it has six branch offices spread throughout East Kalimantan, namely in Samarinda, Tenggarong, Bontang, Balikpapan, Berau and Sangatta. In September 2020, East Kalimantan LAZ DPU received an award as a participant in the Implementation of the National Zakat Index \& study on the impact of zakat 2020 from the central BAZNAS as a form of accountability for 
the donation of Zakat Infaq and Alms which managed by East Kalimantan LAZ DPU. During this covid-19 period, East Kalimantan LAZ DPU had various innovations related to zakat management, including the use of technology as a form of digitizing zakat management.

\section{ZIS Fundraising at East Kalimantan LAZ DPU in Pandemic}

Need analysis is the first thing that must be considered for fundraising amil to increase the trust of muzakki/donors at East Kalimantan LAZ DPU by providing the best service to muzakki. To raise ZIS funds, several steps which had been taken by East Kalimantan LAZ DPU in various form, such as socialization. In attracting the trust of muzakki to pay zakat, infaq and alms at East Kalimantan LAZ DPU, socialization was done both face to face and nonface to face, publishing various existing programs or some programs which will be carried out by East Kalimantan LAZ DPU through print media and social media in the form of a website: lazdpukaltim.or.id, Facebook, Linkedin, Instagram and Youtube and WhatApp application.

Second, Excellent service. In terms of excellent service to muzakki East Kalimantan LAZ DPU have been providing various payment services, namely either directly or indirectly or the muzakki directly come to the East Kalimantan LAZ DPU office in all branch offices, as well as zakat pick-up services including infaq and alms by visiting house of muzakki, for muzakki, every month on the agreed date, the amil will come to the house to collect ZIS funds. In addition, to provide easiness in paying ZIS, East Kalimantan LAZ DPU provides services by opening accounts at various banks such as BNI Syariah, BSM, so that muzakki can easily pay ZIS funds which will be distributed by transfer system. Besides that, East Kalimantan LAZ DPU has utilized digital technology and also opened easy payments by simply scanning the QRIS barcode for several applications that have collaborated with East Kalimantan LAZ DPU, such as the DANA application, OVO, Go Pay, Link Aja, ShopeePay and other applications.

Third, Fundraising. The form of collecting ZIS funds is not only in the form of money, but with some various programs which are beneficial for community in getting money, such as alms with giving cooking oil (unused cooking oil), the LAZ DPU who will process that unused cooking oil, saving waste with the bank program (environmentally friendly program). This program not only makes money but gives benefits to the environment.

Fourth, Literacy. To increase the interest of muzakki, East Kalimantan LAZ DPU opens their mind by conducting various studies, both zakat studies, qurban fiqh studies and so on.

Fifth, Maintenance. Maintenance also has an important role in the quality of ZIS collection at East Kalimantan LAZ DPU. Maintenance is done to 
establish good relationship with the muzakki by always keeping good relation like visiting the muzakki directly or indirectly, such as asking for their news via telephone or WhatsApp, praying for the muzakki and updating every program that will be launched by East Kalimantan LAZ DPU.

Sixth, Financial Report. Financial Reporting is very important in form of financial reporting data and the distribution of ZIS funds as well as proof of depositing zakat both physically and digitally via email which can be used as an attachment to make an Annual SPT for Zakat as a deduction for taxable income. Financial reporting is the main thing which given by East Kalimantan LAZ DPU to muzakki to maintain the trust of the muzakki in East Kalimantan LAZ DPU with the predicate of WTP (reasonable without exception) where all financial reports present fairly, in term of all material aspects and financial reports may be known by public regarding how much of the collection and distribution of funds that have been used. This is in accordance with Yasni \& Erlanda (2020) one of the stepping stones in integrating zakat which is very suitable for the current pandemic situation is to apply zakat as a tax deduction. The Fundrising Program of DPU LAZ East Kalimantan shown on Figure 2.

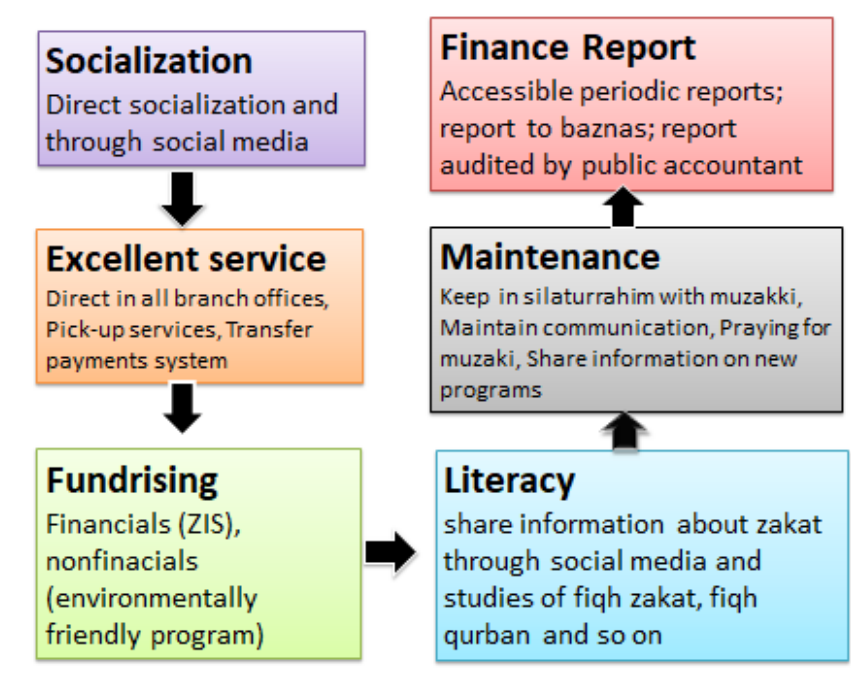

Figure 2. Fundrising Program of DPU LAZ East Kalimantan Source: DPU LAZ East Kalimantan (2021)

\section{Distribution of ZIS Funds at LAZ DPU East Kalimantan In This Pandemic}

The distribution activities are one of the most important functions of East Kalimantan LAZ DPU. Various forms of distribution were done in the atmosphere of this covid -19 pandemic, the form of distribution was also directed at handling the impact of covid-19 for Mustahik to relieve Mustahik economic difficulties.

The distribution program of ZIS fund at East Kalimantan LAZ DPU was divided into 5 areas, first Humanity Field. The distribution of zakat, infaq and 
alms in the humanitarian field includes non-productive Mustahik assistance and natural and humanitarian disasters such as war and refugees in Islamic world. The distribution in the field of humanity is a distribution that is about fully charitable distribution to help meet the basic needs of life. The distribution of non-productive Mustahik assistance is very possible to be distributed regularly considering the non-productive condition of Mustahik, such as beneficiaries who are very old and in need. Some of humanitarian programs which offered by East Kalimantan LAZ DPU include:

a. Dhuafa Care Compensation which is prioritized for the poor who are non-productive and unable to meet the needs of a decent living.

b. Disaster Response Action is a humanitarian program which focuses on responding quickly to natural disasters. This program began with the Disaster Volunteer Action of East Kalimantan LAZ DPU. Then continued with the collection of donation and distributed as soon as possible based on the need in the field and in coordination with the task force which appointed by the relevant government.

c. Humanitarian Assistance for Islamic World, in the form of distributing Infaq specifically for the Islamic World which was raised to help our brothers and sisters in parts of Islamic countries affected by war, starving, plague and economic blockades and it is expected to be able to raise our concern for our brothers who are in squeezed conditions in parts of Islamic countries.

Second, the distribution of zakat, infaq, alms and other socio-religious funds through the field of da'wah is expected to be able to strengthen the syiar of Islamic da'wah echoed by the $d a^{\prime} i$ and da'iyah specially to maintain the faith and dignity of the ummah in East Kalimantan. The All Programs showed by Figure 3. Some programs in the field of da'wah include:

a. The assistance of Da'i Care for the Ummah is in the form of assistance which given to Islamic preachers who care about the condition of ummah and strengthens the condition of non-Islamic faith through taklim assemblies, community relation. The assistance is in the form of cash funds, fulfilling the needs of the preacher's life, providing BPJS health insurance for the Islamic preacher.

b. The assistance for the Koranic Teacher Community in Dhuafa or poor Community, in the form of operational funds for the Qur'an teacher who teaches children from the poor community to build awareness in poor families to protect the Qur'an.

c. Da'i scholarship is given to Islamic preachers who want to learn and improve their knowledge to strengthen da'wah in East Kalimantan. 
d. Bina Muallaf program is conducted in a coaching community to understand Islamic values and become a person who is strong in worship and has good character.

Next, the distribution of ZIS in the health sector is one of the concerns of East Kalimantan LAZ DPU because health is a very important pillar of life, especially for the poor. The distribution of ZIS in the health sector will bring a piece of mind to the beneficiaries if their health declines at any time. Partnership synergy is offered to several clinics closest to the Dhuafa or poor community as well as medical teams so that they will be able to provide services for the beneficiaries. Several programs in the health sector include the Dhuafa Health Clinic; Mass Circumcision; Public Medical Check Up Program Health; Mobile Clinic; and Health Care program for Mother and Children.

Another important sector is economics. The distribution of Zakat, Infaq and Alms in the economic field is one of the focuses of East Kalimantan LAZ DPU in empowering the poor to be able to improve welfare and become independent at an economic level. The main target in the distribution of zakat, infaq and alms in this field is that the poor can develop a mindset of being empowered, assisted in business development, and can remove the poor gradually from the entanglement of moneylenders who usually provide capital loans or fulfil the daily needs of the poor who can finally trap the poor families to be more slumped in powerlessness.

The programs which are given to the poor in the economic aspect are 1) Bina Mandiri, namely individual assistance to be assisted in term of business training, small capital, business opening, business assistance and mentoring from East Kalimantan LAZ DPU partners. Bina Mandiri program is declared to be productive and successful, at least adding insight in business management so that it can develop, and then it can be facilitated for the East Kalimantan LAZ DPU partners who can develop even bigger businesses; 2) Productive Development is assistance which is managed by the society in poor community in a joint effort to become a centre for product production that can be an alternative choice for people in East Kalimantan to meet their daily needs. Productive development usually starts from communities who want to be assisted and involved in helping family finances and are active in social activities.

Next, Education is one of the main areas in the focus of the LAZ DPU, East Kalimantan especially in the program of distributing funds of zakat, infaq and alms because education is one of the doors in removing the poor from the poverty trap. Qualified education, good facilities and infrastructure can support the increase of children' literacy power in East Kalimantan to later become children who excel, have high fighting power, and care for each 
other to bring East Kalimantan into a province that contributes to have superior generation for Indonesia. Several Empowerment Programs in the Education Sector include PENA (Guidance Program for Foster Children), Education Packages and National Cheerful Program for Children.

Last, Care for Covid 19. Besides the regular distribution program, during this covid-19 pandemic, the program will increase by handling the impact of covid-19 in the form of 1) Personal Protective Equipment assistance for Medical Workers; 2) Frontline Best Nutrition Program; 3) providing Basic food for the poor; 4) Empowerment of students and teachers during pandemic.

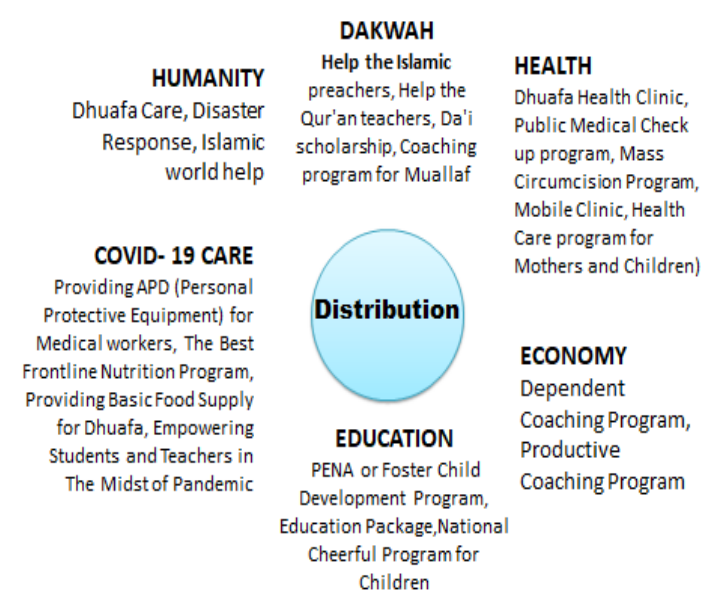

Figure 3: The Distribution Program of LAZ DPU East Kalimantan Source: DPU LAZ East Kalimantan (2021)

Some programs for collecting and distributing ZIS at East Kalimantan LAZ DPU have been designed with various innovative programs to attract muzakki to donate at East Kalimantan LAZ DPU. This innovation program is very helpful for Mustahik, especially during pandemic. The innovation programs are: Tabung Yatim; Health Program for the poor who have serious illness; Jariyah Alms for Tahfidz Qur'an Boarding School; Friday Wholesale Charity Alms in giving Wrapped Rice; Joint Venture of Tahfidz's Parents; Independence Program (Productive Business Development); Program of 100 Iqro Books and the Qur'an; Construction of Water Towers and Drilling Wells; Hafidz Qur'an Scholarship; Renovation program of Mustahik House; The Alms of Used cooking oil and Bank; and Sacrifice Program of Inland Cow.

\section{CONCLUSION}

In this Covid 19 pandemic, the use of digital technology in all fields is unavoidable, including the management of zakat. The use of digital technology in zakat management is very urgent, to improve time efficiency, some easiness and other advantages as well as optimizing the potential 
instruments of Islamic social financial. The Amil Zakat Institution of East Kalimantan through Ummah Care Fund has innovated in zakat management by utilizing digital technology both in the collection and distribution of ZIS funds, such as socialization program and reporting on various social media, use of e-banking and QRIS, zakat pick-up services and active communication with muzakki as well as zakat facilities as tax deduction. In the distribution of ZIS funds, it is directed at handling the impact of covid-19 for Mustahik to relieve Mustahik economic difficulties, through regular programs in the fields of humanity, da'wah, health, economy, and education. In addition, some special programs were added, namely helping medical personnel by providing personal protective equipment, the Best Frontline Nutrition Program, providing basic food supply for dhuafa, empowering students and teachers during this pandemic. In addition, to optimize the collection and distribution of East Kalimantan LAZ DPU branch has innovated some appropriate and targeted products, especially in this pandemic.

\section{REFERENCES}

Almeida, F., \& Santos, J. D. (2020). The effects of COVID-19 on job security and unemployment in Portugal. International Journal of Sociology and Social Policy, 40(9-10), 995-1003. https://doi.org/10.1108/IJSSP-07-20200291

Amanda, G. R., Malihah, F., Indriyastuti, S., Khumairah, N., Tulasmi, T., \& Mukti, T. (2021). Pendayagunaan Zakat Pada Masa Pandemi Covid-19. Jurnal Ilmiah Ekonomi Islam, 7(1), 216. https://doi.org/10.29040/jiei.v7i1.1789

Ansoriyah, F., Warella, Y., Purnaweni, H., \& Hastuti, R. S. (2020). Responses to Pandemic Covid-19 by Mosque-Based Zakat Agency: Opportunities and Limitations in Zakat Management. Dinika Academic Journal Of Islmic Studies, 5(2), iii-189. http://ejournal.iainsurakarta.ac.id/index.php/ dinika/article/view/2764

Asfarina, M., Ascarya, A., \& Beik, I. S. (2019). Re-Estimating the Zakat Potential in Indonesia Based on Classical and Contemporary Fiqh Approaches. Journal of Islamic Monetary Economics and Finance, 5(2), 387-418. https://doi.org/10.21098/jimf.v5i2.1068

Bahri, E. S., \& Khumaini, S. (2020). Analisis Efektivitas Penyaluran Zakat pada Badan Amil Zakat Nasional. Al Maal: Journal of Islamic Economics and Banking, 1(2), 164. https://doi.org/10.31000/almaal.v1i2.1878

Bambra, C., Riordan, R., Ford, J., \& Matthews, F. (2020). The COVID-19 pandemic and health inequalities. Journal of Epidemiology and Community Health, 74(11), 964-968. https://doi.org/10.1136/jech2020-214401

Baskoro, B. D., \& Karmanto, G. D. (2020). Intensi Masyarakat Dalam Menyalurkan Zakat, Infaq, Dan Shadaqah (Zis) Melalui Penggunaan Platform Crowdfunding. Point, 2(2), 95-109. https://doi.org/10.46918/point.v2i2.748 
Beik, I. S., \& Arsyianti, L. D. (2013). Optimization of Zakat Instrument in Indonesia' s Poverty Alleviation Programme. 'Poverty Alleviation and Islamic Economics and Finance: Current Issues and Future Prospect,' May 2013, 1-19. https://doi.org/10.13140/RG.2.1.2491.2720

Bernauer, W., \& Slowey, G. (2020). COVID-19, extractive industries, and indigenous communities in Canada: Notes towards a political economy research agenda. The Extractive Industries and Society, 7(3), 844-846.

BPS. (2020). Pertumbuhan Ekonomi Indonesia. Badan Pusat Statistik. https://www.bps.go.id/pressrelease/2020/11/05/1738/ekonomiindonesia-triwulan-iii-2020-tumbuh-5-05-persen--q-to-q-.html

Chakraborty, I., \& Maity, P. (2020). COVID-19 outbreak: Migration, effects on society, global environment and prevention. Science of the Total Environment, 728(January). https://doi.org/10.1016/j.scitotenv.2020. 138882

Eichhorst, W., Marx, P., \& Rinne, U. (2020). Manoeuvring Through the Crisis: Labour Market and Social Policies During the COVID-19 Pandemic. Intereconomics, 55(6), 375-380. https://doi.org/10.1007/s10272-0200937-6

Hassan, M. K. (2010). An Integrated Poverty Alleviation Model Combining Zakat, Awqaf and Micro-Finance. Seventh International Conference- The Tawhidi Epistemology: Zakat and Awqaf Economy, 262-281.

Hudaefi, F. A., Caraka, R. E., \& Wahid, H. (2021). Zakat administration in times of COVID-19 pandemic in Indonesia: a knowledge discovery via text mining. International Journal of Islamic and Middle Eastern Finance and Management. https://doi.org/10.1108/IMEFM-05-2020-0250

Ibn-Mohammed, T., Mustapha, K. B., Godsell, J., Adamu, Z., Babatunde, K. A., Akintade, D. D., Acquaye, A., Fujii, H., Ndiaye, M. M., Yamoah, F. A., \& Koh, S. C. L. (2021). A critical review of the impacts of COVID-19 on the global economy and ecosystems and opportunities for circular economy strategies. Resources, Conservation and Recycling, 164(May 2020), 105169. https://doi.org/10.1016/j.resconrec.2020.105169

Iskandar, A., Possumah, B. T., \& Aqbar, K. (2020). Peran Ekonomi dan Keuangan Sosial Islam saat Pandemi Covid-19. SALAM: Jurnal Sosial Dan Budaya Syar-I, 7(7). https://doi.org/10.15408/sjsbs.v7i7.15544

Karmaker, C. L., Ahmed, T., Ahmed, S., Ali, S. M., Moktadir, M. A., \& Kabir, G. (2021). Improving supply chain sustainability in the context of COVID19 pandemic in an emerging economy: Exploring drivers using an integrated model. Sustainable Production and Consumption, 26(January), 411-427. https://doi.org/10.1016/j.spc.2020.09.019

Mofijur, M., Fattah, I. M. R., Alam, A., \& Islam, A. B. M. S. (2020). Since January 2020 Elsevier has created a COVID-19 resource centre with free information in English and Mandarin on the novel coronavirus COVID19. The COVID-19 resource centre is hosted on Elsevier Connect, the company' s public news and information. Sustainable Production and Consumption, 26(April), 343-359.

Muneeza, A., \& Nadwi, S. (2019). The Potential of Application of TechnologyBased Innovations for Zakat Administration in India. International 
Journal of Zakat, 4(2), 87-100. https://doi.org/10.37706/ijaz.v4i2.191

Newbold, S. C., Finnoff, D., Thunström, L., Ashworth, M., \& Shogren, J. F. (2020). Effects of Physical Distancing to Control COVID-19 on Public Health, the Economy, and the Environment. Environmental and Resource Economics, 76(4), 705-729. https://doi.org/10.1007/s10640020-00440-1

Nurhidayat, N. (2020). Strategi Fundraising Zakat Pasca Pandemi Covid-19. SALAM: Jurnal Sosial Dan Budaya Syar-I, 7(8), 737-748. https://doi.org/10.15408/sjsbs.v7i8.16553

Rachman, M. A., \& Salam, A. N. (2018). The Reinforcement of Zakat Management through Financial Technology Systems. International Journal of Zakat, 3(1), 57-69. https://doi.org/10.37706/iconz.2018.122

Rohim, A. N. (2019). Optimalisasi Penghimpunan Zakat Melalui Digital Fundraising. Al-Balagh: Jurnal Dakwah Dan Komunikasi, 4(1), 59-90. https://doi.org/https://doi.org/10.22515/balagh.v4i1.1556

Shaikh, S. A. (2016). Zakat Collectible in OIC Countries for Poverty Alleviation: A Primer on Empirical Estimation. International Journal of Zakat, 1(1), 17-35.

Soleh, M. (2019). Zakat Fundraising Strategy: Opportunities and Challenges in Digital Era. Journal of Nahdlatul Ulama Studies, 1(1), 1-16. https://doi.org/10.35672/jnus.v1i1.4

Sugiyono. (2017). Metode Penelitian Kualitatif dan R and D. In Bandung: CV. Alfabeta.

Tiirinki, H., Tynkkynen, L. K., Sovala, M., Atkins, S., Koivusalo, M., Rautiainen, P., Jormanainen, V., \& Keskimäki, I. (2020). COVID-19 pandemic in Finland - Preliminary analysis on health system response and economic consequences. Health Policy and Technology, 9(4), 649-662. https://doi.org/10.1016/j.hlpt.2020.08.005

Trougakos, J. P., Chawla, N., \& McCarthy, J. M. (2020). Working in a pandemic: Exploring the impact of COVID-19 health anxiety on work, family, and health outcomes. Journal of Applied Psychology, 105(11), 1234-1245. https://doi.org/10.1037/apl0000739

Wang, Z., \& Tang, K. (2020). Combating COVID-19: health equity matters. Nature Medicine, 26(4), 458. https://doi.org/10.1038/s41591-0200823-6

World Health Organization. (2020). Laboratory testing for coronavirus disease ( COVID-19) in suspected human cases: interim guidance, 19 March 2020 (No. WHO/COVID-19/laboratory/2020.5). World Health Organization.

Yasni, R., \& Erlanda, A. R. R. (2020). Challenges of Zakat Integration as Source of State Revenue. International Journal of Islamic Economics and Finance (IJIEF), 3(3), 175-204. https://doi.org/10.18196/ijief.3238 